\title{
Constitutional Adjudication by Parliaments: Lessons from Comparative Experience
}

Belachew Girma*

\begin{abstract}
This article explores historical experiences in France and Brazil and the contemporary constitutional set-up in China where parliaments are empowered to adjudicate constitutional issues. It also identifies the lessons thereof for the constitutional design in Ethiopia. Comparison among three legal regimes has been made with regard to the rationales and contexts under which legislative or nonlegislative parliaments were entrusted with the power of interpreting constitutions. The experience in France (1799 to 1946), Brazil (1824-1891) and China's current practice in constitutional interpretation are examined. The experiences across time in different jurisdictions are used to analyze the extent to which (non-)legislative assemblies are appropriate organs to adjudicate constitutional issues. The Constitution of Ethiopia is expected to take lessons from the difficulties encountered from the experiences of France, Brazil and China and resort to other institutional choices for constitutional adjudication.
\end{abstract}

\section{Key terms}

Constitutional adjudication · Constitutional courts · Parliament $\cdot$ House of Federation

DOI http://dx.doi.org/10.4314/mlr.v12i1.2

Received: 27 February 2018

Accepted: 7 September 2018

This article is licensed under a Creative Commons Attribution-NonCommercialNoDerivs (CC BY-NC-ND)

\footnotetext{
* Belachew Girma Degefie, LL.B (Bahir Dar University), LL.M in Constitutional and Public Law (Addis Ababa University), LL.M in Comparative Constitutional Law (Central European University); currently Attorney and Consultant at Law.

Email: girma.belachew@yahoo.com

Frequently used acronyms

CCI Council of Constitutional Inquiry

CPC Communist Party of China

HoF House of Federation

HoPR House of Peoples' Representatives

NPC National People's Congress (China)

NPCSC National People's Congress Standing Committee (China)

NNPs Nations, Nationalities and Peoples
} 


\section{Introduction}

The current Ethiopian Constitution adopts ethnic federalism by accommodating diversity as 'building bricks' of the federal system. ${ }^{1}$ One third of the constitutional provisions deal with human rights including socio-economic and environmental rights, and it gives due attention to the rights of women, child rights etc. The Constitution declares that the federation is established by the 'free' agreement ${ }^{2}$ of Nations, Nationalities and Peoples (hereinafter the 'NNPs'); and it also declares that Sovereign political power resides in them.

The Constitution was, however, criticized because of its making process and content. Many scholars have contested its legitimacy arguing that the making process did not include significant political actors, the discussions were more of educational rather than taking inputs from the population, and the whole process was dominated by the Ethiopian Peoples' Revolutionary Democratic Front (hereinafter 'EPRDF') and hence it lacks original legitimacy. ${ }^{3}$ Others also criticized it on the ground that the federal structure tilts more towards the 'selfrule' rather than the 'shared rule' ${ }^{4}$ considering it as a 'recipe for disaster'. The existence of highly centralized political party which has dominated the political sphere since the promulgation of the Constitution was also considered as making the federal arrangement 'dysfunctional'.

Absence of strong form of constitutional review which keeps government organs within their constitutional limits was also another criticism. The Constitution empowers the House of Federation (hereinafter 'the HoF'), assisted by the Council of Constitutional Inquiry (hereinafter 'the CCI'), as an organ empowered to interpret the Constitution. Some criticize this mechanism of constitutional adjudication as highly politicized indicating 'absence of effective domestic safeguards against regression into rule by law ${ }^{\prime 6}$ rather than rule of law. Others criticize it stating that it silences ordinary courts from protecting human

\footnotetext{
${ }^{1}$ See generally Assefa Fiseha (2006), Federalism and the Accommodation of Diversity in Ethiopia: Comparative Study, Wolf Legal Publishers, The Netherlands.

${ }^{2}$ The Constitution of the Federal Democratic Republic of Ethiopia, 1995, Federal Negarit Gazeta, Proc. No. 1/1995, No.1, 1st year 1995,Paragraph 1 of the Preamble.

${ }^{3}$ See for instance, Tsegaye Regassa (2010), "The Making and legitimacy of the Ethiopian Constitution: Towards Bridging the gap between Constitutional Design and Constitutional Practice", Africa Focus, Volume 10, No.1, pp. 85-118. Available at: <www.gap.ugent.be/africafocus/pdf/vol23_1_making.pdf>

${ }_{5}^{4}$ See for instance, Assefa Fiseha, supra note 1, pp. 297-300.

${ }^{5}$ See for instance, Aberra Degefa (2005), "The Scope of Rights of National Minorities under the Constitution of FDRE", Series on Ethiopian Constitutional Law, Volume 1.

${ }^{6}$ Adem K. Abebe (2012), "Rule by law in Ethiopia: Rendering constitutional limits on government power nonsensical", CGHR Working Paper 1, Cambridge: University of Cambridge Centre of Governance and Human Rights, pp. 15-16. Available at: <https://www.repository.cam.ac.uk/handle/1810/245111>
} 
rights and the HoF lacks the requisite independence to exercise the necessary checks and balances against government organs and as such does not protect human rights. ${ }^{7}$ There is plentiful scholarly literature that critically analyses the fact that the HoF cannot effectively interpret the Constitution, as a result of different recommendations are forwarded.

The tradition of empowering parliaments to interpret constitutions in socialist states was more common and currently exists in China where the National People's Congress (hereinafter the 'NPC) is empowered to do so by virtue of Article 62 of the 1982 Constitution. This arrangement was categorized as one of the weak forms of constitutional review which gave unlimited power to the government and ultimately to the Communist Party of China (hereinafter 'the CPC'). ${ }^{8}$ Therefore, Ethiopia should draw lessons from historical and contemporary failures and difficulties.

So far, scholarly works have addressed the issue of whether a parliament could effectively interpret constitutions both theoretically and in practice. ${ }^{9}$ But, this issue has not been explored from historical perspectives by comparing similar past arrangements with the current ones. The main purpose of this article is to explore the experiences of constitutional adjudication by parliaments in France before 1946, Brazil before 1891 and contemporary China with a view to drawing some lessons to Ethiopia.

Historically, France and Brazil have experienced failure in such arrangement which led to other institutional arrangements: France to Conseil Constitutionnel and Brazil to the Supreme Court. The contemporary constitutional arrangement

${ }^{7}$ Chi Mgbako et al (2008), "Silencing the Ethiopian Courts: Non-Judicial Constitutional Review and its Impact on Human Rights", Fordham International Law Journal, Vol. 32, Issue 1, pp. 259- 297. Available at <http://ir.lawnet.fordham.edu/ilj/vol32/iss1/15/>

${ }^{8}$ See for instance, Cheng Xueyang (2014), "Institutional Developments, Academic Debates and Legal Practices of the Constitutional Review in China: 2000-2013", Frontiers of Law in China, 9: pp. 636-656. Available at <http://academic.hep.com.cn/flc/EN/10.3868/s050003-014-0040-1>; Guobin Zhu (2010), "Constitutional Review in China: An Unaccomplished Project or a Mirage?”, Suffolk University Law Review, 43: pp. 593-624. Available at <https://papers.ssrn.com/sol3/papers.cfm?abstract_id=1664949\&download=yes>

${ }^{9}$ See for instance, Assefa Fiseha (2007), "Constitutional Adjudication in Ethiopia: Exploring the Experience of the House of Federation", Mizan Law Review, Vol. 1, No. 1 pp. 1-32; Getachew Assefa (2010), "All About Words: Discovering the Intention of the Makers of the Ethiopian Constitution on the Scope and Meaning of Constitutional Interpretation", Journal of Ethiopian Law, Vol. 24, No. 2; Tsegaye Regassa (2009), "Making Legal Sense of Human Rights: The Judicial Role in Protecting Human Rights in Ethiopia", Mizan Law Review, Vol. 3, No. 2, pp. 288-330; Takele Soboka (2011), "Judicial Referral of Constitutional Disputes in Ethiopia: From Practice to Theory", African Journal of International and Comparative Law, Edinburgh University Press, Vol. 19, No.1. 
of China is selected as a case study for several reasons. China is one of the very few, if not the only jurisdiction besides Ethiopia, to uniquely empower the legislative body to interpret the Constitution. As the purpose of this article is to show historical failures/difficulties of such arrangements and draw lessons to Ethiopia, the historical and current experiences of China adds an interesting and useful insight. The ideological resemblance between the regimes that shaped constitution-making in both jurisdictions adds another justification to include China's experience to this comparison. Therefore, an overview of the historical context that led to such constitutional arrangement in China is discussed along with some practical insights with the same purpose of deriving lessons to Ethiopia. The article, however, does not go further into the issue of which institutional arrangement is suitable for Ethiopia.

The first section of this article discusses the reasons why constitutions are interpreted and the commonly known institutional choices that should adjudicate constitutional disputes. Regardless of differences in institutions, constitutional adjudication has the purpose of at least ensuring supremacy of the constitutions, defining the scope of fundamental rights and as such protects them from acts of government organs that violate rights and adjudicating disputes among government organs. In view of these objectives, two common models of constitutional adjudication have been identified. The first model is the decentralized model where ordinary courts can interpret the constitution, while in the second centralized model a single specialized court is charged with the task. Constitutional adjudication by (non-)legislative parliaments has also been a rare institutional choice which is currently used in two countries.

The second section explores and analyses the experience of France between the 1789 French Revolution until the 1946 Constitution where the Sénat was empowered to review the constitutionality of legislations. The rationale is also discussed along with the context which led to such arrangement. This section discusses the 1824 Constitution of Brazil where the General Assembly was given the task of constitutional interpretation. It also identifies the lessons that should be derived from the experiences of France and Brazil to similar contemporary arrangements in Ethiopia.

The third and fourth sections deal with constitutional adjudication in China by the NPC with its Standing Committee (hereinafter 'the NPCSC) and in Ethiopia by the HoF/CCI by focusing on why (non-)legislative assemblies are empowered to interpret the constitutions. The reasons that triggered such arrangements are partly similar to the extent that both rely on popular supremacy: supremacy of working people expressed through the supremacy of the NPC and supremacy of the NNPs as exercised by the HoF. However, the NNPs are authors of the Constitution and have final say on it whereas the NPC as the government organ supervises the Constitution. This section also discusses their operations and identifies lessons (to Ethiopia) that can be discerned from 
the failures of the NPC of China. However, the issue of which institutional choice best fits Ethiopia is beyond the scope of this article.

\section{Constitutional Adjudication: Theoretical Foundations}

Constitutional adjudication ${ }^{10}$ has attracted the attention of many scholars across the globe as one of the main areas of comparative constitutional law. Even if the main focus of the article is to explore constitutional adjudication by parliaments particularly in the constitutional history of France and Brazil and similar contemporary arrangements in the constitutions of China and Ethiopia, it would be apt to discuss the reasons why constitutions are interpreted and which institutions are preferred in developed and stable constitutional systems. Hence, this section briefly highlights the reasons why constitutions are interpreted and the common models of constitutional interpretation.

\subsection{The 'why' of constitutional interpretation}

Constitutions are fundamental laws that have the purpose of establishing and structuring governments, guaranteeing fundamental rights and determining the relationship between the government and citizens. They constitute a government and hence governments are expected to conform to this higher law. Constitutions confer legitimacy over government's action and empower a government. ${ }^{11}$ They may also include 'aspirational' functions by 'picturing the best sort of community people could attain through its constitutional arrangements and commandments'. ${ }^{12}$ In the course of 'creating and building up a modern democratic society, the constitution appears as an act of institutionalizing the political system, but also as a means and guarantor of securing the fundamental democratic, political, and social relations'. ${ }^{13}$

Constitutional interpretation refers to the task of safeguarding the supremacy of a constitution and keeping laws and actions of government within the constitutional limits. Constitutional interpretation has been considered as one of the main mechanisms to protect fundamental rights enshrined in constitutions

${ }^{10}$ Even if the meaning of the expressions 'constitutional adjudication' and 'constitutional interpretation' may not be exactly the same, they are used interchangeably in this article as it may not have an impact on the issue under consideration.

${ }^{11}$ Walter F. Murphy, James E. Fleming, Sotirios A. Barber (1995), American Constitutional Interpretation, The Foundations Press Inc., New York, p. 3.

${ }^{12}$ Id. p. 4

${ }^{13}$ Pavle Nikolic (2011), "Constitutional Review of Laws by Constitutional Courts and Democracy: Problem of Legitimacy", in Mahendra P. Singh (ed.), Comparative Constitutional Law, Eastern Book Company, Lucknow, p. 38. 
from actions of government by defining the scope of rights. ${ }^{14}$ Legislation enacted by either the lawmaker or executive organ should be checked for compatibility with the constitution primarily with a view to check whether such acts of government violate fundamental rights, and secondarily to keep balance of power among organs of government themselves. ${ }^{15}$ Therefore, constitutional interpretation is generally a means of ascertaining supremacy of constitutions.

Depending on jurisdictions, constitutional interpretation may have one or more of the following proposes: to limit governmental powers, to keep supremacy of constitutions by ensuring that all laws and decisions conform to the constitution, and to keep balance of power in federations. Constitutions in federal countries include agreements and bargains hence considered as 'covenant'. There should be an impartial arbiter to solve disputes that may arise on division of power between the two levels of government. ${ }^{16}$

One of the reasons to interpret constitutions may be that clauses or phrases of constitutional texts are unclear as to their meanings. Framers of constitutions often adopt flexible language to make a workable constitution or owing to difficulties of including compromises and balancing of values. ${ }^{17}$ James Madison identified three sources of difficulties in framing the US Constitution: the complexity of the relations to be regulated, the imperfections of human notions about politics, and the inadequacy of words to convey complex ideas with precision and accuracy. ${ }^{18}$ Hence, constitutions are interpreted in order to clarify clauses and phrases which are not clear to apply to particular cases.

Some clauses in constitutional texts may appear in potential conflict with others in order to apply them to particular cases. ${ }^{19}$ Some other constitutional clauses may have been framed very broadly or some parts of the constitutional text may be read as if it takes away what it granted by another clause. It is

${ }^{14}$ See generally Armen Mazmanyan et al (2013), "Constitutional Courts and Multilevel Governance in Europe: Editors' Introduction”, in Armen Mazmanyan et al (eds.)(2013), The Role of Constitutional Courts in Multilevel Governance, Intersentia Publishing Ltd., Cambridge.

${ }^{15}$ In France, interpreting a constitution was done primarily to inhibit the legislature from encroaching upon the powers of the executive. It was only in 1971 that the Conseil Constitutionnel decided that it also safeguards fundamental rights. See Sophie Boyron (2013), The Constitution of France: A Contextual Analysis, Hart Publishing Ltd., Oxford, pp. 150-151.

${ }^{16}$ See Rudolf Dolzer (2011), 'The Role of the Courts in the Preservation of Federalism:

Some Remarks on the US and the German Experience', in Mahendra P. Singh (ed.), supra note 12 , pp. 69-88.

${ }^{17}$ Murphy et al, supra note 10, p. 9.

${ }^{18}$ Ibid.

${ }^{19}$ Id., p. 10. 
through constitutional interpretation that these constitutional clauses could be applied consistently.

Another reason that justifies interpretation of constitutions may relate to omissions. Although succinct constitutional texts are desired, 'this brevity means that much is left unsaid or only hinted at'. ${ }^{20}$ Constitutional texts may not include all matters to be regulated owing to different reasons. However, such omissions may be remedied either by amendments if it is fundamental, or by interpretation.

Unforeseen developments may necessitate interpretation of constitutions. ${ }^{21}$ In the context of the US Constitution, there were many matters that were not foreseen by the framers but that could be accommodated through constitutional interpretation which helped the Constitution to be the oldest constitution in the world. $^{22}$

In addition to problems and difficulties in constitutional texts, constitutions are interpreted with a view to ensure their supremacy and to ensure compatibility of legislation and executive action with constitutions. Review of constitutionality of legislation by interpreters of constitutions -most often supreme courts and constitutional courts- has been contested on the ground that it undermines democratic principles by empowering unelected judges to nullify legislation enacted by elected representatives which have direct mandate from the people. ${ }^{23}$

\subsection{Models of constitutional interpretation}

Even if there is a consensus that constitutions should be interpreted owing to the reasons discussed above, the issue of who should interpret them has been one of the most controversial issues in constitutional law. In the United States, ordinary courts interpret the Constitution while most European countries have established constitutional courts. ${ }^{24}$ In France, the Conseil Constitutionnel is empowered to interpret the Constitution. In China and Ethiopia, the constitution is interpreted

\footnotetext{
${ }^{20}$ Id., p. 11.

${ }^{21}$ Id., p. 12.

${ }^{22}$ Ibid.

${ }^{23}$ See for instance, Helmut Steinberger, "Aspects of Judicial Review of the Constitutionality of Executive Actions in the Federal Republic of Germany: A Basic Outline", in Mahendra P. Singh (ed.), supra note 13, pp. 29-32; Pavle Nikolic (2011), "Constitutional Review of Laws by Constitutional Courts and Democracy: Problem of Legitimacy", in Mahindra P. Singh (ed.), supra note 13, pp. 33-48.

${ }^{24}$ From among European countries, eighteen of them have established constitutional courts while only three countries have adopted the USA model of judicial review. See in general, Victor Ferreres Comella (2009), Constitutional Courts and Democratic Values: a European Perspective, Yale University Press, New Haven.
} 
by a (non-)legislative chamber. These varieties of institutions indicate the disagreements on which institutions should interpret constitutions.

The role of the organ entrusted with the power of interpreting a constitution includes the following:

a) it ensures the supremacy clause of the Constitution;

b) it provides the ultimate decision in constitutional disputes;

c) in federations, it umpires the division of power between the federal government and the constituent units;

d) it plays an adaptive role to the current change by keeping its spirit; and

e) it enforces human rights.

Given these important functions, institutions established to undertake such tasks are vital and hence should be impartial and independent. Over time, two models of constitutional adjudication have emerged: centralized and decentralized. These two models emerged in different jurisdictions and have their own peculiar features.

\subsubsection{Decentralized model}

In the United States and other countries that follow its practice, the power to interpret the constitution is vested in the ordinary courts which examine regular civil or criminal cases. In many countries, on the other hand, the judicial review power is given to the highest court of the land having jurisdiction both over general law matters and exclusive jurisdiction over all constitutional controversies.

The decentralized model had its origin in the United States, where judicial review remains a most characteristic and unique institution. ${ }^{25}$ The idea of empowering ordinary courts to interpret the Constitution was constructed by interpretation in the Marbury v. Madison where Chief Justice John Marshall reasoned that 'it is emphatically the province and duty of the judicial department to say what the law is' and to apply the constitution as a higher law to ordinary legislation. ${ }^{26}$ Marbury articulated a theory of judicial review in which courts could play a large role in national governance. ${ }^{27}$ In the United States, all judges, state and federal, can decide on constitutional issues. ${ }^{28}$ The authority to review

${ }^{25}$ Mauro Cappelletti (1970), "Judicial Review in Comparative Perspective", California Law Review, Vol. 58, Issue 5, p. 1026. Available at: <http://scholarship.law.berkeley.edu/californialawreview/vol58/iss5/1>

${ }^{26}$ Marbury v. Madison, 5 U.S. 137 (1803).

${ }^{27}$ Mark Tushnet (2000), "Marbury v. Madison and the Theory of Judicial Supremacy", in Robert P. George (ed.)(2000), Great Cases in Constitutional Law, Princeton University Press, Princeton, p. 1.

${ }^{28}$ Vicky Jackson \& Mark Tushnet (2006), Comparative Constitutional Law, Foundation Press, $2^{\text {nd }}$ edition, New York p. 501. 
the constitutionality of legislation is vested inherently in the judiciary in the USA while this task is entrusted upon constitutional courts in many European countries. $^{29}$ The Federal Supreme Court has jurisdiction to review those decisions and could give authoritative interpretations which are binding on lower courts. $^{30}$

The power of judicial review is meant to 'preserve the Constitution as a supreme law of the land' and 'it involves two different missions: one directed towards the states and implicates principle of federalism, and the other addresses acts of executive and legislative branches'. ${ }^{31}$ Ordinary courts could adjudicate constitutional issues only in concrete cases where there are real controversies. Hence, they cannot review constitutionality of legislation in abstract, i.e., in the absence of real disputes between parties.

In order for the parties to bring such issues to the attention of courts, they should fulfil standing requirements: injury in fact, nexus between the injury and the unlawful act and redressability. ${ }^{32}$ These requirements are among the strict rules of standing to bring constitutional questions. '[I]t is in principle only the violation of a party interest which puts in motion the procedure of legislation'. 33 It may then be questionable whether it is possible to contest the constitutionality of legislation which may not relate to a particular individual interest but affect the public at large. ${ }^{34}$

${ }^{29}$ Alec Stone Sweet (2012), "Constitutional Courts", in Michel Rosenfield and Andras Sayo (eds.)(2012), The Oxford Handbook of Comparative Constitutional Law, Oxford University Press, Oxford, p. 818.

${ }^{30}$ Ibid.

${ }^{31}$ Maeva Marcus (1995), "The Founding Fathers, Marbury vs Madison- and So What?" In Eivind Smith (ed.)(1995), Constitutional Justice under Old Constitutions, Kluwer Law International, The Hague, p. 25.

${ }^{32}$ Alen v. Wright 468 U.S. 737 (1984).

${ }^{33}$ Hans Kelsen (1942), "Judicial Review of Legislation: A Comparative Study of the Austrian and the American Constitution", The Journal of Politics, Vol. 4, No. 2, p. 193. Available at <http://www.journals.uchicago.edu/doi/abs/10.2307/2125770>

${ }^{34}$ Here, environmental cases may be good examples. In Massachusetts v. EPA, the U.S. Supreme Court decided that Massachusetts has standing to sue the Federal Environmental Protection Agency for failure to regulate the emission of 'green gases' which contributed to global warming. However, there are cases like Valley Forge Christian College $v$. Americans United, 454 U.S. 464 (1982) where the claim against the constitutionality of act of the federal government (giving a real estate to a private Christian university under the supervision of a religious order as a violation of the 'Establishment Clause') was rejected on the ground that the plaintiffs did not show the injury they suffered. See Norman Dorsen et al. (eds.), Comparative Constitutionalism: Cases and Materials (St. Paul: Thomson/West, 2nd edition, 2010) pp. 168-170. 
Decisions rendered by the US Federal Supreme Court on the unconstitutionality of legislation are binding on all parties, and government organs cannot apply the statute anymore. It also serves as a precedent that binds lower courts in entertaining similar constitutional issues.

\subsubsection{Centralized model}

The centralized model of constitutional review emerged in Europe after World War I. ${ }^{35}$ It was proposed by Hans Kelsen and was first established in Austria where he also served as constitutional judge. ${ }^{36}$ Kelsen feared that authorizing ordinary courts to refuse the application of unconstitutional legislation would create non-uniformity in constitutional questions. ${ }^{37} \mathrm{He}$ also added that owing to the existence of administrative courts, contradiction among the decisions of courts was inevitable. ${ }^{38}$ Absence of precedence in many European countries was another reason for Kelsen to propose a different approach to constitutional adjudication than that of the US. Hence, he argued that these reasons necessitate the centralization of judicial review of legislation. The 1920Austrian Constitution reserved judicial review of legislation to a special court called constitutional court. ${ }^{39}$

There are different explanations why most European countries rejected the US model of constitutional adjudication. Part of the explanation focuses on the principle of separation of powers that emerged during the French Revolution of 1789 and spread to many European countries, where judges were to have limited role. ${ }^{40}$ Many scholars have criticized this explanation on the ground that even if "it is important in explaining the rise of special bodies like constitutional courts in Europe, it does not give us justificatory reasons for their existence and for the particular details of their design". ${ }^{41}$

The second explanation is that European civil law countries cannot achieve legal certainty with the design similar to decentralized system of constitutional

${ }^{35}$ Victor Ferreres Comella (2004), "The European Model of Constitutional Review of Legislation: Toward Decentralization?", ICON, Vol. 2, No. 3, p. 461, <icon.oxfordjournals.org/content/2/3/461.full.pdf>, last visited 04/04/2017

${ }^{36}$ See John E. Ferejohn (2004), "Constitutional review in the Global Context", Legislation and Public Policy, 6: pp. 49-59. Ferejohn argues that the Kelsean model of constitutional review spread throughout Europe because they wanted to enforce constitutional provisions after the collapse of authoritarian regimes.

${ }^{37}$ Kelsen, supra note 33, pp. 184-186.

${ }^{38}$ Ibid.

${ }^{39}$ Ibid.

${ }^{40}$ Comella, supra note 24 , p. 10 . Developments which led to restricting the role of courts in reviewing legislation will be discussed in detail in Part two.

${ }^{41}$ Id., p. 19. 
adjudication. ${ }^{42}$ The reasons include the existence of more than one supreme court because courts are specialized in different areas of the law and the doctrine of precedent does not serve as one of the sources of law in the civil law tradition. ${ }^{43}$ Therefore, the centralized model of constitutional review was partly explained by the conception of separation of powers and legal certainty.

The centralized model of constitutional review refers to the existence of one single organ to interpret constitutions. A constitutional court is an independent organ of the state with the task of primarily ensuring superiority of the constitutional norm. ${ }^{44}$ In other words, it is only the constitutional court that reviews constitutionality of legislation and declare it unconstitutional. Portugal is one exception in that in addition to establishing constitutional court, it also empowers ordinary courts to set aside legislation they deem unconstitutional, but reserving the power to nullify such legislation only to the constitutional court. ${ }^{45}$ In addition, ordinary courts in some countries are empowered to set aside legislation that was enacted before the constitution came into force. ${ }^{46}$

With respect to tasks allocated to constitutional courts other than reviewing the constitutionality of legislation, some courts have jurisdiction to supervise the regularity of election and referenda, to verify the legality of political parties or to enforce the criminal law against higher government officials. ${ }^{47}$ As Comella notes, "[t]he more important those other functions are, the larger the workload they generate, and the closer they are conceptually to the enforcement of ordinary law, the less pure constitutional court is". 48

The issue as to who could bring cases to constitutional courts is important. The first type of procedure is through constitutional challenges, to be submitted by public institutions which challenge legislation in abstract in the absence of any controversy. ${ }^{49}$ A statute may be challenged before or after promulgation in different jurisdictions. The second type of procedure is through constitutional questions initiated during litigation in ordinary courts where judges stay proceedings and send the constitutional issue to the constitutional court if the ordinary court believes that a statute applicable in that particular case is unconstitutional. ${ }^{50}$ Some countries like Germany and Spain provide for a third

\footnotetext{
${ }^{42}$ This justification was brought by Hans Kelsen. See Kelsen, supra note 33.

${ }^{43}$ Comella, supra note 24, p. 21.

${ }^{44}$ Stone Sweet, supra note 29, p.817.

${ }^{45}$ Comella, supra note 35 , p. 463.

${ }^{46}$ Comella, supra note 24, p. 6.

${ }^{47}$ Ibid.

${ }^{48}$ Id., p. 6

${ }^{49}$ Id., p. 7

${ }^{50}$ Ibid.
} 
type of procedure where individuals can file a constitutional complaint alleging that their fundamental rights have been violated. ${ }^{51}$

Constitutional courts often review the constitutionality of legislation prior to the promulgation of laws. Such control of legislation is called 'abstract review' which implies the absence of cases and controversies unlike the decentralized model. Here, a constitutional court 'opines on the constitutionality of proposed or enacted legislation without regard to the application' ${ }^{52}$ France has been an archetypal for 'pure' abstract review until the Conseil Constitutionnel was empowered in 2008 to review the constitutionality of legislation in concrete cases. $^{53}$

\subsection{Constitutional adjudication by (non-)legislative houses}

At this juncture, it is important to mention that review of constitutionality of legislation by courts is not automatic. Institutional choices vary across jurisdictions. Even in the United States where there is strong judicial review, there are debates relating to whether it is compatible with democratic principles to allow unelected judge to quash legislation enacted by representatives which have direct mandate from the people. Many European countries have chosen constitutional courts. Some other jurisdictions have made a different arrangement by granting this power to (non-)legislative assemblies which are the focus of this article.

In the spectrum of institutional choices empowered to adjudicate constitutional issues, one could find parliaments with or without legislative powers in some jurisdictions. There were some historical incidences where parliaments were empowered with such task. In France, since the Revolution of 1789 up to the enactment of the 1946 Constitution, the Senat was the organ which used to adjudicate constitutional disputes. The Imperial Constitution of Brazil enacted in 1824 (on the verge of its independence) was another example where the Senate was empowered to interpret the Constitution.

There are also contemporary examples for such arrangement. Currently, China and Ethiopia stand at odds as jurisdictions which empower a legislative and non-legislative parliament to interpret their constitutions. ${ }^{54}$ The 1982 Constitution of Peoples' Republic of China authorizes the NPC to 'supervise the

\footnotetext{
51 Ibid.

${ }^{52}$ Michael C. Dorf (2009), “Abstract and Concrete Review”, in Vikram David Amar and Mark V. Tushnet (eds.)(2009), Global Perspectives on Constitutional Law, Oxford University press, New York, p. 3.

${ }^{53}$ Ibid.

${ }^{54}$ See Article 62(1) of the Ethiopian Constitution and Article 62(2) of the Constitution of Peoples Republic of China.
} 
enforcement of the Constitution'. ${ }^{55}$ The NPC is also supported by the Standing Committee which undertakes routine tasks of the NPC. Similarly, Article 62 of the 1995 Constitution of the Federal Republic of Ethiopia authorizes the HoF (an upper chamber) to, inter alia, 'interpret the Constitution'. The experiences of constitutional adjudication in the jurisdictions mentioned above are discussed in detail in the next two sections.

\section{Historical Failures/Difficulties of Constitutional Adjudication by Parliaments in France and Brazil}

Constitutional history and comparative law shows that there were constitutions which empowered parliaments to adjudicate constitutional disputes. As has been highlighted in the preceding section, the constitutional history of France and Brazil can provide lessons to similar contemporary designs.

\subsection{Constitutions of France between 1799 and 1946}

After the French Revolution of 1789, courts were deliberately restricted, by law, from interfering in the legislative and administrative functions. The Sénat was instead empowered to interpret the constitution. There are explanations given to such arrangements.

\subsubsection{The reactions of the revolutionaries and the Sénat}

During the old regime (ancien régime), the parlements ${ }^{56}$ had active roles in the government process. Many historians consider the parlements as the last reflection of the tension between the aristocracy and the monarchy ${ }^{57}$ as they resisted many reforms. Particularly, the refusal of the Parlement of Paris to register edicts (that created new offices and which embodied reforms on monetary and fiscal controls and edicts of tax reforms) gave provincial parlements the same view and claims of resisting reforms by the aristocracy and the King. ${ }^{58}$

Within the ancien régime, parlements had an active role in the legislative process; they could reject laws declared by the Kings. The courts had the right of remonstrance, which entitled them to refuse to register a King's decree which

${ }_{55}^{55}$ Article 62(2) of the Constitution of Peoples Republic of China.

${ }^{56}$ Parlements were appellate courts of the ancien regime in France. Initially, there was only one Parlement, that of Paris. Later, other parlements were created in the provinces. See Encyclopedia Britannica. Available at: <https://www.britannica.com/topic/Parlement>

${ }^{57}$ William Doyle (1970), "The Parlements of France and the Breakdown of the Old Regime 1771-1788", French Historical Studies, Vol. 6, No. 4, p. 415.

${ }^{58}$ Martin A. Rogoff (2011), French Constitutional Law: Cases and Materials, California Academic Press, Durham, p. 126. 
(they believed) violates the 'fundamental law' -principles that were developed in the courts for a long time. ${ }^{59}$ The judges of parlements affirmed that they had the power and obligation to 'examine edicts and laws of the Kings' against the fundamental law. ${ }^{60}$

By the 1750s, 'the parlements had emerged as an articulate and determined opposition, resisting every effort at moderate reform that successive ministers sought to propose'. ${ }^{61}$ There were frequent and stiff confrontations between the parlements and the King, which compelled the latter to make some reforms in the judiciary. This in turn led to judicial strikes thereby creating a tense relationship among them. ${ }^{62}$ These powerful courts kept their control over the King for a longer time until the eve of the Revolution.

The French Revolution responded in a 'hostile' manner to the powerful and arbitrary role played previously by the judiciary. ${ }^{63}$ This hostility to the role of judges has led the French constitutional thought for nearly two centuries to have the notion of 'political' judicial review. ${ }^{64}$ There were several measures that aimed at excluding ordinary courts from the task of reviewing legislation. Such hostile approach began to take action in 1790 where a judicial reform was introduced by the Constituent Assembly, which required judges to apply and interpret statutes and precluded them from taking part in law-making functions. ${ }^{65}$ Similar prohibition against judges was incorporated in the 1791 and 1795 Constitutions.

The reaction against the role of courts in the ancien regime yielded different attempts to exclude the judiciary from the purview of constitutional review of

${ }^{59}$ James Beardsley (1975), “Constitutional Review in France”, Supreme Court Review, Vol. 1975, p. 191.

The requirement of registration of king's edicts and ordinances originally had a narrow and practical function of providing the parlement with a reliable text which later was considered by the crown to be an essential requirement. See for instance Rogoff, supra note 58, p.125.

${ }^{60}$ Mauro Cappelletti and John Clarke Adams (1966), “Judicial Review of Legislation: European Antecedents and Adaptations", Harvard Law Review, 79: p. 1210. Courts used to refer traditional higher laws of the kingdom as 'fundamental law' as there was no written constitution. See also Comella, supra note 24, p. 12.

${ }^{61}$ Rogoff, supra note 58, p. 126.

${ }^{62}$ Id, pp. 418-420. For instance, the famous edict of Chancellor Rene-Nicolas de Maupeou in 1770 forbade strikes, suspension of service, mass resignation, and cooperation between parlements, all of which were considered by parlements as 'sweeping and unjust attack' on their public role over several decades. In 1771, Maupeou suggested for the parlements to be abolished and replaced by conseil superieurs, even if it was rejected by the King.

${ }^{63}$ George D. Brown (1966), "DeGaulle's Republic and the Rule of Law: Judicial Review and the Conseil d'Etat", Boston University Law Review, 46: pp. 462-463.

${ }^{64}$ See Beardsley, supra note 59, pp. 189-260.

${ }^{65}$ Id., p. 192. 
legislation which went through different proposals: in 1792, a special bench of 'censors' was proposed to be established within the legislature; in 1793, a 'national grand jury' was proposed to vindicate the rights of citizens oppressed by the legislature; in 1795, a 'jurie constitutionnaire' was proposed to hear complaints relating to the unconstitutionality of legislation. ${ }^{66}$ These proposals helped prepare the terrain for a system of non-judicial review of constitutionality of legislation introduced in the 1799 Constitution, which empowered the Sénat with such review.

With a view to limiting the powers of courts, a référé facultatif was instituted which obliged judges to look for binding interpretation of laws from the legislature in cases where they had doubts as to the meaning of a law. ${ }^{67}$ 'Even the Tribunal de cassation, which was established in 1790-1791, originally had an extra judicial and essentially legislative nature'. ${ }^{6}$ This Tribunal had the power of quashing judicial decisions which it considered conflicting with the letter of the law. ${ }^{69}$ As Cappelletti and Adams noted, if "the courts to which the case was then remanded persisted in the decision that the Tribunal had declared illegal, the case was referred to the legislature by the so-called référé obligatoire for a binding interpretation of the law". ${ }^{70}$ These were some of the mechanisms of excluding courts from the process of making law to the extent of controlling how courts used to interpret legislation.

With regard to the attempts to restrain courts from interfering in administrative functions, the task of legal validity of administrative acts was assumed by the Conseil de'Etat under the 1799 Constitution as a separate institution from the judiciary. ${ }^{71}$ Later on, the Conseil de'Etat was followed by lower administrative courts. Hence, it could be said that the Conseil de'Etat was the result of reactions of the revolutionaries against parlement's role in administrative functions.

The Sénat conservateur was empowered by the Constitution of 1799 to check the constitutionality of legislation enacted by the Parliament. Beardsley states that the Constitution 'empowered the Sénat as the guardian of the Constitution and that no statute might be promulgated without first being submitted to the Sénat, whose duty was to 'oppose' the promulgation of unconstitutional

\footnotetext{
${ }^{66}$ Id., pp. 208-209.

${ }^{67}$ Cappelletti and Adams, supra note 60, p. 1212.

${ }^{68}$ Ibid. The Tribunal de cassation was later developed into a judicial organ named Cour de Cassation.

${ }^{69}$ Ibid.

${ }^{70}$ Ibid. The institutions of référé facultative and référé obligatoire were later abandoned.

${ }^{71}$ Comella, supra note 24, p. 13.
} 
legislation. ${ }^{72}$ This was a direct response to the previous role of parlements and it prohibited them from engaging in reviewing the constitutionality of legislation. The same trend continued in the Constitution of 1852, and subsequently, it came to be deeply rooted in French constitutional law that rejected judicial review of legislation.

Therefore, the reforms after the Revolution to minimize the role of prerevolution parlements started first by excluding them from taking part in the legislative and administrative functions. Then, it went onto allocating the power of interpreting the constitutions to the Sénat. This arrangement rejected the leading role of ordinary courts and paved a new era of constitutional interpretation by parliaments.

One may wonder how the Sénat was composed and whether it was suitable to exercise its power of checking the constitutionality of legislation. The Sénat was composed of members recruited by co-option from a list of candidates submitted by the Corps législatif, the Tribunal and the First Consul. According to Article 21 of the Constitution of 1799, the Sénat had the power to either maintain or annul acts referred to it by the Tribunal or the Government. It had no power to review the constitutionality of legislation after it was promulgated. However, the Sénat did not exercise its power of constitutional review until its disappearance from the Constitution in 1815. This is one clear lesson that constitutional adjudication by legislature has never worked.

Despite the failure of the previous constitutional arrangement in making the legislature as constitution interpreter, the Sénat revived again in the 1852 Constitution with a slight difference from its predecessor in its composition, but with the same power of constitutional adjudication, among other powers. It was composed of cardinals, marshals, and admirals of the Republic as well as other persons as the President of the Republic might wish to appoint. Similar to the previous arrangement, the Sénat was considered as the guardian of the Constitution and statutes were required to pass through its review. This Constitution also allowed citizens to refer their constitutional concerns on draft legislation to the Sénat before promulgation. Once again, the Sénat did not annul any law as unconstitutional ${ }^{73}$ proving further that it is not an appropriate body to review the constitutionality of legislation.

The attempt made to review the constitutionality of legislation by the Sénat was not successful because it was under the complete political dependence of the Emperor and therefore "lacked the necessary institutional distance to

\footnotetext{
${ }^{72}$ Beardsley, supra note 59, p. 194.

${ }^{73}$ Ibid.
} 
evaluate the laws". ${ }^{74}$ The ineffectiveness of the political body to exercise review of constitutionality of legislation was criticized by renowned French scholars. ${ }^{75}$

In addition to the pressures to exclude the judiciary from the law-making process, courts used to defer cases which involved interpretation of constitutions. For instance, many decisions by the Court of Cassation, like the case of affaire Paulin, were disposed by deference on the ground that statutes adopted and promulgated could not be challenged on the basis of unconstitutionality. ${ }^{76} \mathrm{~A}$ similar approach was followed by the Conseil d'Etat when it encountered the issue for the first time in $1901 .^{77}$

Hostility of the revolutionaries towards the parlements of the ancien regime ended up by excluding them from taking part in the law-making process and administrative functions. Then, the power of constitutional adjudication ended up with the Sénat by authorizing it as a guardian of the constitutions. Despite its important role of constitutional adjudicator in other jurisdictions, the Sénat did not entertain cases, as a result of which it was later replaced by the Constitutional Committee under the 1946 Constitution.

\subsubsection{The rationales}

There are some explanations why the Sénat (in France) was empowered to review the constitutionality of legislation from the time of the French Revolution up to the establishment of the Constitutional Committee under the 1946 Constitution. These conceptions of the constitutionality review of legislation have influenced jurisdictions across Europe which later resorted to the establishment of constitutional courts.

The first justification forwarded for not adopting judicial review of legislation by courts was 'the theory of separation of powers underlying the revolutionary legislation'. ${ }^{78}$ According to the French democratic political theory, judicial review would be inconsistent with the theory of separation of powers. ${ }^{79}$ The Revolutionaries relied more on the legislature and executive as institutions of social transformation 'to liberate the people from feudal privileges' ${ }^{80}$ Hence, 'judicial functions' were understood to be 'distinct and separate' from

\footnotetext{
${ }^{74}$ Comella, supra note 24 , p. 14

${ }^{75}$ Beardsley, supra note 59, p. 210.

${ }^{76}$ Id. p. 193. Beardsley mentions that the Court of Cassation had also reviewed substance of statutes in some cases but, later returned to 'impermissibility of intervention by the judges in the legislative power.'

${ }^{77}$ Id., p. 194.

${ }^{78}$ Id., p. 193. See also Rogoff, supra note 58, p. $168 \mathrm{ff}$.

${ }^{79}$ Cappelletti and Adams, supra note 60, p. 1211.

${ }^{80}$ Comella, supra note 24, p. 11.
} 
legislative and administrative functions. Codification of laws guaranteeing individual rights and principles of equality helped to limit the role of judges. ${ }^{81}$

The issue of the organ that has to interpret the constitutions was a point of contention during the enactment of the 1946 Constitution which resulted in the establishment of the Constitutional Committee. The Constitutional Committee was empowered to decide whether legislation was in contradiction with the organic part of the constitution and constitutional amendment was required to validly enact statute. ${ }^{82}$ This arrangement, too, kept the traditional understanding of separation of powers by allocating review of constitutionality of legislation to an organ outside the judiciary.

The second rationale behind authorizing the Sénat to review the constitutionality of legislation was the supremacy of laws as an expression of 'general will'.

'Largely because of these abuses of the judicial function, the ideology of the Revolution, enshrined in the works of Rousseau and Montesquieu, stressed the omnipotence of statutory law, the equality of man before the law, and the rigid separation of powers in which the judge, the passive bouche de la loi (mouthpiece of the law), performed the sole task of applying the letter of the law to individual cases' ${ }^{83}$

The legislature, as the voice of popular and national sovereignty, was seen as the best guarantor of fundamental rights, and ultimately of the constitutions. The traditional conception of separation of powers that prevailed in France since the Revolution and the supremacy of la loi as an expression of the 'general will' were the rationales behind empowering the Sénat as an organ interpreting the constitutions. It was against the background of the powerful courts in the regimes preceding the Revolution that the Revolutionaries provided these reasons to exclude courts from the ambit of constitutional interpretation and allocated it to the Sénat.

The institutional choices made in the subsequent constitutions of France were overshadowed by the past experiences of 'distrust of courts' owing to the conception of separation of powers and supremacy of the law (la loi) on the one hand and the failures of the Sénat to properly function as constitution interpreter. In light of these historical incidents, the 1946 Constitution envisaged the power of constitutional interpretation to the Constitutional Committee. The framers of this Constitution had no 'sense of conferring ordinary courts a power

\footnotetext{
${ }^{81}$ Ibid.

${ }^{82}$ Id., p. 14.

${ }^{83}$ Cappelletti supra note 25, p. 1026.
} 
of control over the constitutionality of laws'. ${ }^{84}$ The Constitutional Committee was designed to be more political than the in its composition and role. ${ }^{85}$ The power allocated to it by the Constitution was deliberate which seemed incongruent with comparative experience that enables the judiciary to check whether the 'laws voted by the National Assembly presuppose an amendment of the Constitution'. ${ }^{86}$ This implies that the principles of supremacy of la loi and separation of powers are in tandem with the constitutional history of the France.

The Constitutional Committee assembled only once in twelve years which led to the establishment of the Conseil Constitutionnel, also known as the Constitutional Council, under the 1958 Constitution. The principal reason for the establishment of the Constitutional Council was 'to prevent Parliament from legislating outside of the matters which were assigned to it' ${ }^{87}$ by the Constitution. Ousted from the task of interpreting a constitution for historical reasons, the French judiciary was not once again a choice for the framers of the 1958 Constitution.

The changes in the institutional choices made to discharge the task of constitutional review in the constitutions of France resulted in the failure of the Sénat to adjudicate constitutional disputes. The practical failures of the Sénat coupled with the historical incidents that shaped the constitutional history of France directed the framers to come up with an institutional choice that came to be 'uniquely French'. 88

\subsection{Brazil under the 1824 monarchical constitution}

Brazil's Imperial Constitution of 1824 was enacted upon independence from Portuguese colonization. The Constitution established 'a monarchic, inherited, constitutional and representative government' ${ }^{89}$ The constitutional arrangement

\footnotetext{
${ }^{84}$ Marcel Waline (1963), "The Constitutional Council of the French Republic", The American Journal of Comparative Law, Vol. 12, p. 484.

${ }^{85}$ Ibid. It comprised the President of the Republic, as president, the Presidents of the assemblies forming the Parliament, which then were called the National Assembly and the Council of the Republic, seven members elected by the National Assembly at the commencement of each annual session, on the basis of proportional representation of its groups, and chosen outside its membership, and finally, three members elected on the same terms by the Council of the Republic.

${ }^{86}$ The 1946 Constitution of France.

${ }^{87}$ Waline, supra note 84 , p. 485 . This Council was also intended to serve as guarantor of the regularity of the functioning of these institutions.

${ }^{88}$ Ibid. The Constitutional Council, established as separate entity from the structure of ordinary judiciary, stands as unique especially when compared with constitutional courts that are more common in Europe. Its composition and powers make it unique.

${ }^{89}$ Charles D. Cole (2008), Comparative Constitutional Law: Brazil and the United States, Vandeplas Publishing, Lake Mary, p. 27.
} 
relating to constitutional adjudication under the 1824 Constitution of Brazil and the rationales for such choice are highlighted below.

\subsubsection{The General Assembly as interpreter of the Constitution}

With respect to its making process, the Emperor rejected proposals of a 'Constitutional Convention' and called a group of prominent figures 'a State Council' and enacted a text drawn up by them. ${ }^{12}$ Although it was not the fruit of social pressures or a democratic conquest, it was a rather liberal charter. ${ }^{90}$ The Emperor had a significant role in the lawmaking process and influenced the content of the constitution which granted him a wider political power. The Constitution was in force until 1889.

According to Article 10 of the Constitution, political power was comprised of 'legislative, 'moderating,'91, executive and judicial powers'. ${ }^{92}$ Legislative power was allocated to the General Assembly which was composed of two bodies: The Chambers of Deputies and the Senate. ${ }^{93}$ One of the functions of the General Assembly listed under Article 15 of the Constitution was 'to watch over the Constitution and to promote the wellbeing of the nation'. It also had the power to make, to interpret, to suspend and to repeal laws. ${ }^{94}$ This arrangement was similar with that of France's constitutional history discussed above except for the fact that the General Assembly of Brazil under 1824 Constitution was composed of both chambers.

These constitutional texts clearly granted the power to interpret the Constitution to the legislative organ, the General Assembly. Such an arrangement was made due to the dominating role of the Emperor, who had a unique 'moderating power' which allowed him to control all other organs of government. The Emperor was described as 'supreme chief of the nation' and was empowered to 'incessantly watch over the maintenance of independence, the equilibrium and harmony of the other political powers'. ${ }^{95}$

The 'moderating' power of the Emperor included nominating Senators, convoking extraordinary General Assemblies, sanctioning the decrees and resolutions of the General Assembly and giving them the force of laws, and

${ }^{90}$ Samantha S. Moura Ribeiro (2016), Democracy after the Internet - Brazil between Facts, Norms, and Code, Springer International Publishing, Switzerland, p. 65. Available at <http://www.springer.com/kr/book/9783319335926>.

${ }^{91}$ This concept of 'moderating power' that was created by the Constitution in addition to the legislative, executive and judicial powers is explained below.

${ }^{92}$ Article 10 of the 1824 Imperial Constitution of Brazil (hereafter 'the 1824 Constitution of Brazil').

${ }^{93}$ Id., Articles 13 and 14.

${ }^{94}$ Id., Article 14.

${ }^{95}$ Id., Article 98. 
dissolving the Chamber of Deputies. ${ }^{96}$ The Emperor was the chief of the executive and exercised this power through his Ministers of State. ${ }^{97}$ All these powers of the Emperor remained unchecked because the General Assembly -an entity supposed to keep the supremacy of the Constitution- was under the control of the Emperor.

\subsubsection{The rationales}

The creation of the 'moderating' power of the Emperor may be explained by the fact that the issue of national unity along with new institutions after independence had to be handled by the centralizing power of the Emperor. ${ }^{98}$ This power of the Emperor helped him to limit powers of the local and regional government which were deemed to be a threat to national unity. ${ }^{99}$ If stronger constitutional review mechanisms were envisaged in the Constitution, it may have, supposedly, hampered the Emperor's exercise of power.

The 1891 Constitution, which established the First Republic, was largely taken from the Constitution of the United States. It established a federal presidential system, separation of powers, checks and balances, and institutions. The period of monopoly of power by the Emperor came to an end with this Constitution. The provinces were given the status of sub-units and power was allocated between the two levels of government.

The empowerment of the legislatures in both France and Brazil as constitutional adjudicator was justified by pragmatic considerations: France's difficulty of having powerful courts which led to their exclusion from reviewing legislation and administrative action on the grounds of separation of powers and supremacy of la loi, and Brazil's justification of establishing strong central government to keep the country unified against the interests of strong provinces. However, the difference lies in the degree of influence in the subsequent constitutions. In France, the influence of the ideals of the revolutionaries on separation of powers and supremacy of la loi remained deeply rooted in the constitutional jurisprudence of the country whereas it ceased to exist in Brazil as early as 1891 .

The role of the judiciary in constitutional adjudication was secondary during the pre-republican period of the imperial regime in Brazil. Under the 1891 Constitution, the role of interpreting the Constitution was granted to the Supreme Court. The 1891 Constitution introduced judicial review 'which expressly authorized the judiciary to review all matters, laws and executive

\footnotetext{
${ }^{96}$ Id., Article 101(I) - (V).

${ }^{97}$ Id., Article 102.

${ }^{98}$ Cole, supra note 89 , p. 28.

${ }^{99}$ Ibid.
} 
orders, for consistency with the constitution'. ${ }^{100}$ Since then, the Supreme Court of Brazil interprets constitutions which were changed several times.

\subsection{Ineffective constitutional adjudication in France (Pre-1946) and Brazil (Pre-1891)}

The history of France and Brazil discussed above indicates that constitutional adjudication by parliaments was not functional. In France, parlements were excluded from the ambit of 'legislative power' owing to their pre-revolution dominant roles. The main rationales for empowering the Sénat were supremacy of la loi and separation of powers. The failure of the Sénat, however, indicates that parliaments are not appropriate bodies to adjudicate constitutional issues. In addition, 'a political organ with effective powers of constitutional review and the requisite independence would have been too powerful, displacing the Government itself. ${ }^{, 101}$ Subsequent changes that were brought to this arrangement took into account these same rationales, but with the belief that stronger checks on the constitutionality of laws and executive actions were necessary.

The case in Brazil was different in that the Emperor consolidated his power of dominating all branches of government with a view to centralizing political power. The threat to the central government came from the provinces and the Emperor had concentrated power to limit powers of the regional and local governments and defend the unity if the country. Stronger form of judicial review mechanism was not thus desired.

Both constitutional arrangements were in force for more than 150 years in France and for more than 60 years in Brazil. However, both legislatures were not effective in constitutional adjudication. Eventually, these jurisdictions resorted to granting constitutional adjudication to a different body: France first to Constitutional Committee then to Conseil Constitutionnel and Brazil to the Supreme Court.

\section{Constitutional Adjudication by National People's Congress in China}

The current institutional choice for constitutional adjudication in China was heavily shaped by the arrangements in the constitutions preceding it. There were four written constitutions in the constitutional history of China. This section briefly discusses the constitutional history preceding the 1982 Constitution and looks into the powers of the constitutional supervision and interpretation by the NPC and NCPCSC.

\footnotetext{
${ }^{100}$ Id., p. 34,

${ }^{101}$ Beardslay, supra note 59, p. 10.
} 


\subsection{Constitutional adjudication in China since 1954}

Chinese constitutional history after the fall of feudal monarchy in 1911 is explained by struggles between traditional Confucian ideas, western constitutionalism and communism. Four written constitutions were enacted since the 1950s, all of which were characterized as typical examples of constitutions without constitutionalism. ${ }^{102}$

In 1949, the Political Consultative Committee was established which was composed of political parties and associations mostly dominated by the Communist Party of China (hereinafter the 'CCP'). ${ }^{103}$ The Consultative Committee adopted provisional Common Programme which laid down new principles for all subsequent constitutions. ${ }^{104}$ This document proclaimed a 'people's democratic dictatorship' to refer to "power based on a 'united front' made up of classes of workers, peasants, petty and national bourgeois". ${ }^{105}$ The Common Programme influenced constitutions enacted afterwards. The Preamble of the 1954 Constitution states that it was enacted 'based on the Common Programme of the Chinese People's Political Consultative Conference of 1949 and is a development of it". ${ }^{106}$ The current Constitution has taken various institutional arrangements including constitutional adjudication from the 1954 Constitution.

The first written socialist constitution, which was a prototype for the current Constitution, was enacted in 1954. Among other things, the 1954 Constitution had established NPC and NPCSC, the State President, the State Council, and Local People's Congress (LPC), and it has the same structure with the current Constitution. However, the 1954 Constitution 'was not implemented with serious effort and [it did not] curb calamities of massive scale caused by abuse of state power", thereby causing subsequent constitutional and political changes that affected the contemporary China. ${ }^{107}$ Article 27 of the Constitution empowered the NPC to 'supervise the Constitution'. As there were no

\footnotetext{
${ }^{102}$ Qianfan Zhang (2012), The Constitution of China: A Contextual Analysis, Hart Publishing, Portland, p. 43.

${ }^{103}$ For detailed information on the Political Consultative Committee, see: <http://www.china.org.cn/english/archiveen/27750.htm>

${ }^{104}$ Zhang, supra note 102, p. 44.

105 Ibid.

${ }^{106}$ Paragraph 3 of the Preamble of the 1954 Constitution of People's Republic of China (hereinafter 'the Constitution of China')

${ }^{107}$ Zhang, supra note 102, p. 45.
} 
provisions under the Constitution that deal with constitutional interpretation, it could be assumed that the NPC was intended to exercise this power too. ${ }^{108}$

The rationale behind such an arrangement comes initially from the 1949 Common Programme which required 'democratic centralism' under the dominance of the Communist Party of China. Democratic centralism in the Soviet Union and later in China meant decision-making process adopted by the Communist Party which combined two seemingly opposing ideas of democracy and central control. ${ }^{109}$ Accordingly, all powers belong to the NPC ultimately and to local people's congress at the lower level where decisions should be made collectively (and at times with unanimity). It would be incompatible with the ideas held by the Communist Party if the power to control the NPC and the government through constitutional review was granted to an impartial body. Weak constitutional review mechanism was chosen against this background and continued to be adopted by subsequent constitutions.

Empowerment of the NPC as constitutional adjudicator also relates to the conception of supremacy of the legislature in socialist/communist states as a reflection of sovereignty of the people. Socialist legal systems reject the conception of separation of powers by making the legislature the highest authority of the government; and even if they allocate powers to the three organs of government, these organs have never been equal. ${ }^{110}$ Legislative supremacy rather than empowered judiciary was "recognized as fundamental premise of the socialist ideology". ${ }^{111}$

A similar hostile attitude of French revolutionaries towards the exercise of constitutionality review by courts could be observed in the case of China. The legislative organ was empowered to check constitutionality of state actions as a consequence of its supremacy and "constitutionality review could not be exercised by extra-parliamentary bodies". ${ }^{112}$ Hence, in the case of China, distrust of courts comes from the supremacy of the NPC and its legislations whereas in France, it emerged as a reaction against the powerful courts that existed in the ancien regime. This conception of supremacy of the NPC and its legislation over other organs of the government has shaped the constitutional law of China and its institutional choice of constitutional adjudication.

\footnotetext{
${ }^{108}$ Cai Dingjian (1995), "Constitutional Supervision and Interpretation in the People's Republic of China", Journal of Chinese Law, Vol. 9, pp. 220-221.

${ }^{109}$ Encyclopedia Britannica, Available at < https://www.britannica.com/topic/democraticcentralism>

${ }^{110}$ Rhett Ludwikowski (1988), "Judicial Review in the Socialist Legal System: Current Developments", International and Comparative Law Quarterly, Vol. 37, p. 90.

${ }^{111}$ Ibid.

112 Ibid.
} 
Separation of powers was rejected in the case of China as the NPC was/is supreme. Courts were/are thus excluded from constitutionality review. In France, however, separation of powers was the basis for the French revolutionaries to exclude courts from interfering in the functions of the legislature and executive. The same concept, i.e. separation of powers, which was rejected in one and strictly construed in another, was the basis to exclude courts from the ambit of constitutional review.

During the reign of Mao Zedong, there were many measures that violated the constitution. This situation continued during the Cultural Revolution (19661976). ${ }^{113}$ Then, the NPC convened and enacted the 1975 Constitution and primarily reduced human rights provisions from the previous constitution and abolished procedural safeguards. It added the right to strike and other rights to carryout socialist revolution. ${ }^{114}$ This Constitution 'conflated the party and state functionaries and dramatically enhanced the role of the CPC. ${ }^{115}$ The 1975 Constitution did not provide any institutional mechanism for constitutional interpretation. It was rather a very simplistic articulation of the NPC ${ }^{116}$ with few constitutional provisions.

A third Constitution was enacted in 1978 following Mao Zedong's death. This Constitution made some changes, but it was regarded as a continuation of the social revolution: it deleted some of the leftist provisions and added human rights provisions, and "set the Four Modernizations in industry, agriculture, defence, science and technology". ${ }^{117}$ This Constitution was a re-establishment of the 1954 Constitution with a view to rebuild the political system of the $1950 \mathrm{~s}$ which was destroyed by the Cultural Revolution. ${ }^{118}$ Hence, the power of the NPC to supervise the Constitution was restored. NPCSC was granted the power to take part in constitutional interpretation. ${ }^{119}$ This Constitution was revised twice subsequently before it was replaced by a new constitution in 1982 . Regarding the institutional choices for constitutional adjudication, a similar trend of empowering the NPC continued through the constitutions which were influenced by the communist ideology and the CPC.

\footnotetext{
${ }^{113}$ The Cultural Revolution was launched by Communist Party of China Chairman Mao Zedong during his last decade in power (1966-76) to renew the spirit of the Chinese Revolution. See Encyclopaedia Britannica Available at: <https://www.britannica.com/event/Cultural-Revolution>

${ }^{114}$ Zhang, supra note 102, p. 46.

${ }^{115}$ Id. p. 46. See also articles 15, 22 and 23 of the 1975 Constitution of China.

${ }^{116}$ Dingjian, supra note 108, p. 221.

${ }^{117}$ Zhang, supra note 102, p. 47.

${ }^{118}$ Dingjian, supra note 108, p. 221.

${ }^{119}$ Ibid.
} 


\subsection{Constitutional adjudication under the 1982 Constitution}

The 1982 Constitution was 'necessitated by economic reforms initiated in December 1978' which signified an attempt to embrace free market in socialist state, a project which was started by its predecessors. ${ }^{120}$ It was in fact an attempt to restore pre-Cultural Revolution constitutional system as radical measures taken by revolutionary leaders have destroyed it. The constitution was conservative with respect to its resemblance to its remote predecessor, the 1954 constitution, while the societal contexts were different. ${ }^{121}$ Hence, NPCSC's power to interpret the Constitution was not an invention of the 1982 Constitution, but it was taken from the 1954 Constitution. Proposals to establish a constitutional court by the Constitution Revision Committee was rejected by its own influential members as 'not necessary'. ${ }^{122}$

As Jones observes, there are some 'unusual characteristics' in China's 1982 Constitution even if it is 'recognizable to Westerners' that it has some features from their constitutions and also embodies some features from the Soviet Constitution. ${ }^{123}$ One of these unusual features is the NPC, which is not directly elected by the people, but by a local congress elected by citizens. ${ }^{124}$ According to Article 57 and 58 of the Constitution, the NPC is the highest organ and exercises the legislative power of the state. The NPC could seldom be considered as parliament owing to its big size with more than 3,000 (three thousand) members, and it meets once a year to initiate legislation. ${ }^{125}$

Some of the powers of the NPC, as listed under Article 62, include amending the Constitution, supervising the enforcement of the Constitution, enacting legislation, electing the President and the Premier, appointing the President of the Supreme People's Court and the Procurator-General of the Supreme People's Procuratorate. Even if the NPC has extensive powers under the Constitution, it is considered by many scholars as 'rubber stamp' to the Communist Party as it was translating the policies of the party into legislation. ${ }^{126}$

${ }^{120}$ Surya Deva (2011), "The Constitution of China: What Purpose Does it (Not) Serve?", Jindal Global Law Review, 2: p. 62.

${ }^{121}$ Zhang, supra note 102, p. 48.

${ }^{122}$ Xueyang, supra note 8, p. 636.

${ }^{123}$ William C. Jones (1985), “The Constitution of People's Republic of China”, Washington University Law Review, Vol. 63, Issue 4, p. 707-708.

${ }^{124}$ According to Article 34 of the Constitution of China, all citizens who have attained the age of 18 have the right to elect their representatives in the local congress which in turn elects deputies to the NPC.

125 Jones, supra note 123, p. 708.

${ }^{126}$ See, for instance, Zhu, supra note 8 . There are also scholars who argue that the NPC was reviving as an independent entity through time by raising instances where it rejected the draft bills of the Standing Committee and through internal structures. See Michael W. 
The NPC is composed of deputies elected, for the term of five years, from the 'provinces, autonomous regions, municipalities directly under the Central Government, and the special administrative regions, and of deputies elected from the armed forces'. ${ }^{127}$ Minority nationals have also special representations in the NPC. The Constitution does not fix the total number of seats of the NPC, and it rather grows as prescribed by law.

The NPC meets annually, and its routine activities are undertaken by its permanent body, the Standing Committee which is composed of the Chairman, the Vice-Chairmen, the Secretary-General and Members. ${ }^{128}$ The NPCSC has the same term of office with the NPC whereas the Chairman and Vice-Chairman many not serve for more than two consecutive terms. The NPCSC is responsible and reports to the NPC which may recall and question them. ${ }^{129}$ Article 67, inter alia, recognizes the powers of the NPCSC to interpret the Constitution and supervise its enforcement, enact and amend statutes that do not fall under powers of the NPC, enact and amend statutes when the NPC is not in session, and to interpret the statutes.

Under Article 62 (2) of the Constitution, the NPC has the power to supervise the enforcement of the Constitution while Article 67(1) states the powers of the NPCSC to interpret the Constitution and supervise its enforcement. The 1982 Constitution provides for constitutional review on two grounds. One is Paragraph 12 of the Preamble which clearly declares that the Constitution is "the fundamental law of the state and has supreme legal authority" which has to be observed and obeyed by "the people of all nationalities, all state organs, the armed forces, all political parties and public organizations and all enterprises and undertakings in the country". ${ }^{130}$ The second ground is Article 5 which provides that the Constitution binds all acts of the government entities and no law or regulation may contravene it. The powers of the two organs supervising and interpreting the Constitution emanates from these two constitutional grounds.

The Constitution does not define constitutional supervision or constitutional interpretation. The issue would then be whether these two expressions are interchangeable. Dingjian considers constitutional supervision as an allencompassing phrase that may include 'examining, preventing, correcting and

Dowdle (1997), "The Constitutional Development and Operations of the National People's Congress", Columbia Journal of Asian Law, Vol. 11, No. 1, pp. 1-125.

${ }^{127}$ Articles 59 and 60 of the Constitution of People's Republic of China.

${ }^{128}$ Id., Article 65.

${ }^{129} \mathrm{Id}$., Articles 65 and 69.

${ }^{130}$ Id., Paragraph 12 of the Preamble. 
punishing acts' that are found to be unconstitutional. ${ }^{131}$ This indicates that constitutional supervision may involve reviewing the constitutionality of laws and actions with its own initiative when it finds necessary. The powers of the NPCSC are limited to interpreting the constitution which refers to entertaining concrete cases. Apart from NPCSC's accountability and its duty to report to the NPC, the latter may alter decisions of the former.

The NPC exercises its power of constitutional supervision through what is often called 'legislation supervision'. It supervises and controls legislation and regulations enacted hierarchically from local people's congress to its own laws. The Law of Legislation provides that review of constitutionality is conducted by the NPC and the NPCSC and review of legality is undertaken by the State Council. ${ }^{132}$

Regarding the scope of powers of constitutional supervision, there are debates whether the NPC could exercise its power of constitutional control against the CPC. ${ }^{133}$ Some argue that the Preamble and Article 5 of the Constitution clearly obliges political parties to obey the Constitution, whereas, there are also skeptic views because the CPC controls the NPC in many ways. ${ }^{134}$ A compromise between these views is that the NPC may exercise constitutional supervision but is limited to documents and it can suggest modifications if it finds it to be unconstitutional. ${ }^{135}$

Some cases have been brought before the NPC which tested the constitutional review system and procedures of submitting cases especially since the Qi Yuling Case. ${ }^{136}$ In this case, the Supreme People's Court issued a reply to the lower court's submission on how to apply the laws which explicitly recognized that the infringement of constitutional right to education entails civil liabilities. Many scholars supported the decision on the ground that 'constitutional judicialization' was getting root in China and fundamental rights recognized by the Constitution could be enforced against the government

${ }^{131}$ Dingian, supra note 108 , p. 224.

${ }^{132}$ Zhu, supra note 8, p. 631.

${ }^{133}$ For more detailed discussions in this issue, see for instance, Dingjian, supra note 108, pp. 227-229; Larry Cata Backer (2010), “A Constitutional Court for China within the Chinese Communist Party: Scientific Development and a Re-consideration of the Institutional Role of CCP", Suffolk University Law Review, 43: pp. 101-132.

${ }^{134}$ Dingjian, supra note 108, pp. 227-229.

135 Ibid.

${ }^{136}$ Full text of the decision is available at: http://dx.doi.org/10.2753/CED1061-1932390403 last visited on 3/20/2017. See also Robert J. Morris (2012), "China's Marbury: Qi Yuling v. Chen Xiaoqi - The Once and Future Trial of Both Education \& Constitutionalization", Tsinghua China Law Review, 2: pp. 273- 316. 
through courts. ${ }^{137}$ However, the reply was later in 2008 abolished by the Court itself without mentioning any reason. ${ }^{138}$

In some other instances, courts were kept distant from the ambit of constitutional interpretation even to the extent of not mentioning a constitutional provision in their judgments. Ordinary courts cannot decide on the inconsistency of legal norms of different hierarchy, for instance between local rule enacted by the local people's congress and the legislation enacted by the NPC. ${ }^{139}$ This has weakened the role of courts with respect to the enforcement of human rights. ${ }^{140}$ The same point applies to Ethiopia, as discussed in Section 4.

The issue of who could submit constitutional complaints has never been clear as the system of constitutional review was dormant for a long time. The NPCSC was also reluctant to resolve such constitutional disputes submitted to it in a direct way as a means of checks and balance. Rather, it resorts to political options of convincing the concerned organs to change their regulations. ${ }^{141}$ This indicates the failure of the NPCSC to adjudicate constitutional issues.

Different reasons have been forwarded by scholars for the failure of the NPCSC to exercise its power of constitutional review. The first reason relates to the task of constitutional supervision as an additional power to the organ with inherent legislative power. The NPC and NPCSC are among "the busiest legislatures in the world for enacting laws" $" 142$ and they barely have time for constitutional review. Secondly, instead of checks and balance, per se, cooperation prevails among organs of the government which results in the use of political lines ${ }^{143}$ rather than adjudication. Thirdly, owing to the traditional political culture, NPC shows 'respect to other political organs'. ${ }^{144}$ These and other reasons have contributed for the weak exercise of an already weak

${ }^{137}$ See Morris, Ibid.

${ }^{138}$ Xueyang, supra note 8, p. 643.

${ }^{139}$ For instance, in the Luoyang Seed Case where the judge who pointed out inconsistency of local rule with Seed Law on her way in entertaining civil case between two companies was dismissed. See Xueyang, supra note 8, p. 646.

${ }^{140}$ See for details Guobin Zhu (2013), "Weak Courts, Weak Rights: Assessing the Realization of Constitutional Rights in the PRC Courts", Hong Kong Law Journal, Vol. 43, Part 2, pp. 713-743.

${ }^{141}$ For instance, in the Sun Zhigang Case, the regulation issued by the State Council entitled 'Measures of Custody and Repatriation of Urban Vagrants and Beggars in Cities' was submitted to suggest change by five professors as unconstitutional as it deprives personal freedom through administrative regulations. See Xueyang, supra note 8, pp. 644-645.

${ }^{142}$ Id. p. 648.

143 Ibid.

${ }^{144}$ Ibid. 
constitutional review mechanism. Chinese constitutional review system is not thus effective.

Unlike the constitutional system of Mainland China, the Hong Kong Special Administrative Region (hereinafter Hong Kong SAR) has a different design for constitutional adjudication. The Basic Law of Hong Kong SAR was enacted by NPC as part of its commitment to the Sino-Joint Declaration. ${ }^{145}$ Accordingly, the Basic Law recognizes that Hong Kong remains to be capitalist for 50 years thereby, enabling it to, inter alia, pursue a slightly different constitutional review mechanism based on the notion of 'One Country, Two Systems'. ${ }^{146}$

Basically, the NPCSC is empowered to interpret the Basic Law whereas courts of Hong Kong SAR are entitled to interpret the Basic Law in the course of adjudicating cases reserving the power to interpret provisions of the Basic Law relating to the powers of the Central People's Government and relationship between the two governments. ${ }^{147}$ This is a significant departure from the power of courts in Mainland China.

The Hong Kong SAR, as an autonomous territory within PRC, has a separate court structure from Mainland China. The Court of Final Appeals retains the power to entertain cases based on the Basic Law. It has been seen in practice that there have been debates on the constitutional jurisdictions of Hong Kong SAR courts and that of the NPC where the Court of Final Appeals passed decisions in some cases that the NPCSC found as intruding its power of constitutional supervision. ${ }^{148}$

145 This agreement was signed between China and Britain in 1984 as a result of which China's exercise of sovereignty resumed in 1997. For further historical explanation, See <https://www.britannica.com/topic/reversion-to-Chinese-sovereignty-1020544>

${ }^{146}$ For detailed discussion, see Guangxiang Li (2013), "Constitutional Review in Hong Kong under the 'One Country, Two Systems' Framework: An Inquiry into its Establishment, Justification and Scope”, A Thesis Submitted for the Doctor of Philosophy, Durham University Law School, unpublished. Available at <http://etheses.dur.ac.uk/6966/>

${ }^{147}$ For detailed discussions on how constitutional interpretation works in Hong Kong and debates revolving around the relationship between the Mainland China and Hong Kong, see, for instance, Yash Ghai (2000), "Litigating the Basic Law: Justification, Interpretation and Procedure", \& H L Fu (2000), "Supremacy of a Different Kind: The Constitution. The NPC and the Hong Kong SAR", in Johhanes M M Chan et al (eds.)(2000), Hong Kong's Constitutional Debate: Conflict over Interpretation, Hong Kong University Press, Hong Kong.

${ }^{148}$ See, for instance, Albert H. Y. Chen (2006), "Constitutional Adjudication in Post-1997 Hong Kong”, Pacific Rim Law and Policy Journal, Vol. 15 No. 3, pp. 627-682; Johannes Chan (1999), "Judicial Independence: Controversies on the Constitutional Jurisdiction of the Court of Final Appeal of the Hong Kong Special Administrative Region", The International Lawyer, 33: pp. 1015-1024; Po len Yap (2007), “Constitutional Review 


\section{Constitutional Adjudication by (non-)Legislative Parliament in Ethiopia: House of Federation}

Ethiopia's Monarchical Constitutions of 1931 and 1955, the 1987 PDRE (People's Democratic Republic of Ethiopia) Constitution and the 1995 FDRE (Federal Democratic Republic of Ethiopia) Constitution bear various features with regard to constitutional interpretation. The 1931 Constitution (enacted upon the coronation of Emperor Haile Selassie) had no supremacy clause while the 1955 Revised Constitution had a provision which declared the Constitution to be supreme; but no organ was empowered to ensure supremacy. ${ }^{149}$

The 1987 Constitution declared that it is the supreme law of the land and the National Shengo, a legislative organ, was empowered to 'supervise the observance the Constitution'. ${ }^{150}$ This arrangement resembles the Chinese constitutional choice of the NPC as it recognized the National Shengo as the highest legislative body just like the NPC. It was expected to meet once a year and its routine activities were undertaken by the State Council, an institution similar to the NPCSC. The regime's allegiance to the socialist ideology and its strong relation with the Soviet Union influenced its choices of institutions. The 1987 Constitution was, however, suspended in 1991 by the ethno-nationalist movements who overthrew the regime which made the Constitution shortlived. ${ }^{151}$ As a result, the Constitution was not tested in practice and it is difficult to make comparison with its Chinese counterpart regardless of its similarity in its design.

The 1995 Constitution takes diversity strongly as a response to Ethiopia's immediate history, and it makes identity and language as a basis of granting autonomy. It starts from its Preamble which says, 'We the Nations, Nationalities and Peoples of Ethiopia' by recognizing that Ethiopia is composed of different ethnic groups. The Constitution also makes the Nations, Nationalities and Peoples its authors and declares that the federation is established by their 'free' agreement. ${ }^{152}$ Sovereign political power resides in them. The basis of the federal system is predominantly ethnic and each group is entitled to establish its own

under the Basic Law: The Rise, Retreat and Resurgence of Judicial Power in Hong

Kong", Hong Kong Law Journal.

${ }^{149}$ Article 122 of the 1955 Revised Constitution of Ethiopia.

150 Article 63 of the 1987 Ethiopian Constitution states the power to supervise the observance of the Constitution as one of the powers of the National Shengo.

${ }^{151}$ See, for instance, Assefa Fiseha, supra note 1, pp. 70-79.

152 The Preamble of the FDRE Constitution, paragraph 1. 
state. ${ }^{153}$ The right to promote their culture, language and history, establish selfgovernments and being represented in the federal and state governments are also recognized under Article 39 of the Constitution.

\subsection{Constitutional adjudication under the 1995 Constitution}

Article 62 of the 1995 Constitution grants power to interpret the Constitution to the House of Federation, a second chamber composed of representatives of ethnic groups. Such a unique arrangement was justified by the framers on the ground that the Constitution belongs to the Nations, Nationalities and Peoples and they should be the one who should have final say on it. ${ }^{154}$ Despite the criticisms in academic and political discourse, the arrangement has not been changed.

The HoF is one of the institutions that reflect the accommodative nature of the Constitution in its composition and powers entrusted to it. In addition to interpreting the Constitution, the HoF has powers in deciding on issues, inter alia, relating to self-determination, promoting equality and unity, solving disputes among states, dividing revenues collected from concurrent powers of taxation and subsidies, and ordering federal intervention in the states. ${ }^{155}$

The HoF is assisted by a technical body, called Council of Constitutional Inquiry (CCI), composed of the President and Vice President of the Federal Supreme Court, six legal experts appointed by the President of the Country (Head of State) and three representatives of the HoF. ${ }^{156}$ Membership of the President and Vice President of Federal Supreme Court as President and Vice President of the CCI is automatic, and ipso facto, they lead the CCI.

There are debates on the scope of the power of the HoF to review constitutionality of laws, regulations and decisions of government organs. Some scholars argue that the power of the HoF is limited to reviewing constitutionality of legislation enacted by the federal parliament and state legislatures, leaving constitutionality of laws enacted by the executive at all levels and decisions of government organs to be reviewed by ordinary courts. ${ }^{157}$ Others argue that the HoF has exclusive power to review the constitutionality of all acts of organs of the government on the ground that the framers had no intention of sharing this between the HoF and the judiciary. ${ }^{158}$ These debates are not merely theoretical

\footnotetext{
${ }^{153}$ See Articles 46 and 47 of the FDRE Constitution.

${ }^{154}$ Minutes of the Constitutional Assembly, Volume 5, November 1994, pp. 6-7.

${ }^{155}$ Article 62 of the Constitution of FDRE.

${ }^{156}$ Id., Article 82.

${ }^{157}$ See for instance Assefa Fiseha, Available at http://dx.doi.org/10.4314/mlr.v1i1.55611; Tsegaye Regassa , supra note 9 Available at www.ajol.info/index.php/mlr/article/download/54014/42556.

${ }^{158}$ See in general, Getachew Assefa, supra note 9.
} 
in that they are creating practical problems. Some judges prefer to refer cases to the HoF/CCI when they think that it involves an issue of constitutionality or upon fear of political pressure whereas others adjudicate cases which seem constitutional adjudication per se. ${ }^{159}$

Proclamations No. $251 / 2001^{160}$ and $798 / 2013^{161}$ provide that a case may be submitted either to the HoF, which refers the case to the CCI or to the CCI directly. As it could be understood from Article 84(2) of the Constitution, the CCI investigates the case and if it is convinced that there is violation of the Constitution, then it forwards its recommendation to the HoF for final decision. The HoF, then, undertakes its own investigation based on the recommendation of the CCI, and it reaches at its own decision. In practice, the HoF barely reaches at a different conclusion than the CCI which makes the CCI an important institution in the process of constitutional adjudication in Ethiopia.

\subsection{The rationale for empowering the $\mathrm{HoF}$ as constitutional adjudicator}

The HoF is the representative of NNPs entrusted with the task of interpreting the Constitution in addition to its role as a non-legislative second chamber. In the case of China, the NPC is the legislative assembly which has the highest state authority whereas the HoF is a non-legislative second chamber. The HoF has no legislative power even if there are some powers, which are not legislative, that it may jointly exercise with the House of People's Representatives.

The issues of who should interpret the Constitution and the respective roles of the HoF and ordinary courts have been subject to discourse among scholars during the lawmaking process and thereafter. ${ }^{162}$ The framers of the Constitution justified allocating the power of constitutional interpretation to the HoF on the ground that the Constitution is 'a political contract among the NNPs' and hence

${ }^{159}$ The CUD v. PM Meles Case could be mentioned as an example. For further analysis of the case, see Assefa Fiseha, supra note 157.

${ }^{160}$ Proclamation No. 251/2001, Consolidation of the House of Federation and the Definition of its Powers and Responsibilities Proclamation, Federal Negarit Gazeta, $7^{\text {th }}$ Year, No. 41, $6^{\text {th }}$ July 2001, Addis Ababa. (hereinafter 'Proclamation No. 251/2001)

${ }^{161}$ Proclamation No. 798/2013, Council of Constitutional Inquiry Proclamation, Federal Negarit Gazeta, $19^{\text {th }}$ Year No. 65, 30 ${ }^{\text {th }}$ August 2013, Addis Ababa (hereinafter 'Proclamation No. 798/2013')

${ }^{162}$ See the Minutes of Constituent Assembly, Vol. 4, Discussion on Article 62 of the Constitution; Yonatan Tesfaye (2004), "Who Interprets the Constitution: A Descriptive and Normative Discourse on the Ethiopian Approach to Constitutional Review", unpublished LLM Thesis, Faculty of Law, University of Pretoria; Getahun Kassa (2007), "Mechanisms of Constitutional Control: a Preliminary observation of the Ethiopian System", Africa Focus, Vol. 20, No. 2, pp. 75-104. Available at http://chilot.files.wordpress.com/2011/01/07-20-12-kassa.pdf;Assefa Fiseha, supra note 1.; Getachew Assefa, supra note 9. 
the NNPs should, through their representatives, have final say on what the Constitution says. ${ }^{163}$

The HoF was chosen among other proposals such as ordinary courts and constitutional courts. ${ }^{164}$ The proposal for authorizing courts of any kind was rejected by the framers on two grounds. First, the framers believed that judges would not be neutral from prevailing thoughts in the society and they would erode rights of NNPs under the guise of interpretation. ${ }^{165}$ Secondly, the framers argued that judges cannot be above the people because the NNPs, through their representatives should have power to interpret the Constitution which they have formulated, and they are accorded with the rights and interests in the Constitution. ${ }^{166}$ This suggests that the judiciary was deliberately excluded from interpreting the Constitution for the fear that it may go against the rights of NNPs.

The idea of sharing the power of constitutional interpretation between the $\mathrm{HoF}$ and the judiciary was also raised in the Constituent Assembly. It was suggested that courts could interpret fundamental human rights provisions and the $\mathrm{HoF}$ can reserve the power to interpret those provisions relating to the rights of NNPs. However, it was rejected by the majority of members of the Assembly on the ground that this would not prevent courts from eroding rights of NNPs and it would be difficult to categorize constitutional provisions in this manner. ${ }^{167}$ Therefore, the framers had the intention of granting the power to interpret the Constitution exclusively to the HoF with a view to protect rights of NNPs as authors of the Constitution.

This rationale of the framers of the Constitution may be compared with that of the French revolutionaries who also rejected courts as interpreters of the constitutions. The framers of the Ethiopian Constitution had the intention of

${ }^{163}$ Minutes of the Constituent Assembly, Vol. 4. p. 6. (Note that all translations of

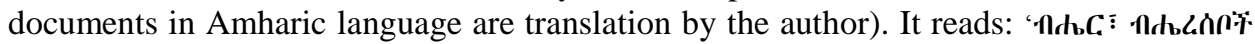

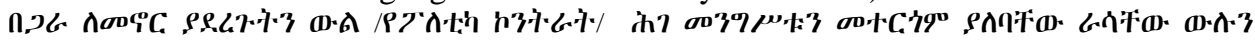

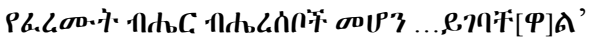

164 The draft constitution indicates that it was a constitutional court that was initially envisaged as the preferred institution to interpret the constitution. However, this was changed when it was presented to the Constituent Assembly.

165 The Constituent Assembly raised the example of judges of US Supreme Court and asserted that the judges interpret the constitution with influences from ideologies of the party that nominates them. See Minutes of the Constituent Assembly, Vol. 4, p.6-7.

166 Ibid.

${ }^{167}$ Id. p. 7. The reason for the rejection of such proposal was explained in the Minutes with an example which states that a state legislature enacts a law that protects NNPs within the region. However, the courts may make decisions against the interests of NNPs on the ground that legislation enacted for their benefit violates rights of individuals. This would create 'constitutional crises'. 
protecting rights of NNPs and enabling them to have the final say on what the Constitution wants to convey as authors, whereas the French revolutionaries responded against the powerful courts of the ancien regime based on the conception of separation of powers and supremacy of la loi. Although the rationale and contexts are different, their view towards courts is the same in that both did not trust ordinary courts.

A similar conclusion may be reached in the cases of Brazil and China. In Brazil, the idea of having a strong central government with powerful Emperor was the main reason for empowering the legislature as constitutional adjudicator implicitly indicating that courts would constrain powers of the Emperor. Likewise, the Chinese Constitution focused on empowering the CPC, as a party leading the country and in light of its allegiance to communist ideology.

Many critics have argued against such an arrangement stating that the HoF is inefficient and is not an impartial body. The reasons relate to the structure and composition of the HoF. Election processes, powers and decision making procedures show that it is a political body and hence not an impartial organ to adjudicate constitutional issues. The HoF is structurally an upper chamber of the federal government which is composed of one representative of all NNPs and one additional member for each one million additional population. ${ }^{168}$ It has no fixed number of seats as its composition depends partly on the population size of NNPs. For instance, the number of seats during the 2010-2014 term was 135. ${ }^{169}$ The number of NNPs represented also varies through time due to seats allocated to new ethnic groups admitted to it based on the requirements under Article 39(5) of the Constitution. ${ }^{170}$ Even if it seems logical that the NNPs (as authors) should interpret the Constitution, HoF does not have institutional independence.

Regarding the mode of election, the members of the HoF may either be directly elected by the people or indirectly by the state legislatures. In practice, the NNPs have never been elected representatives to the HoF. Rather, the State Council of each regional state sends representatives from the state executives. The manner of election both under the Constitution and in practice proves the

\footnotetext{
${ }^{168}$ Article 61 of Constitution of the FDRE.

$169<$ http://www.hofethiopia.gov.et/web/guest/fourth-season-member>. The number of seats of the current term has not shown significant change.

${ }^{170}$ Article 39(5) of the Constitution provides that a Nation, Nationality, People "is a group of people who have or share a large measure of a common culture or similar customs, mutual intelligibility of language, belief in a common or related identities, a common psychological make-up, and who inhabit an identifiable, predominantly contiguous territory". So far, around 75 ethnic groups are represented in the HoF.
} 
political nature of the institution. This practice is similar with that of the NPC of China as their members are not directly elected by the people.

The decision-making process of the HoF creates further difficulty in constitutional adjudication. According to Article 14 of Proclamation No. 251/2001, decisions of the $\mathrm{HoF}$-on cases that involve constitutional interpretation- 'may' be rendered by a unanimous vote of the members who are present. The meaning of the word 'may' is not clear whether it can be interpreted as mandatory, or whether the discretion of choice in deciding based on unanimous vote is given to the HoF. Moreover, the issue of who oversees the exercise of powers of the $\mathrm{HoF}^{171}$ is relevant. Obviously, the CCI, as an advisory body, cannot check the constitutionality of decisions of the HoF. In some jurisdictions, constitutional courts exercise powers (in addition to constitutional adjudication), and such powers include supervising election, referendum, and controlling political parties. Decisions passed by the constitutional courts on these matters remain final.

However, the powers of the HoF are not similar with that of constitutional courts as some of them have regulatory features. For example, if a particular group alleges that they fulfil requirements of Article 39(5) and claim recognition as NNP and rights thereof, then the final and non-appealable decision rests on the HoF. ${ }^{172}$ Another example could be the decision that the HoF passes on the division of revenues collected from the concurrent powers of taxation of the two levels of government. If a constitutional adjudicator has power which is administrative in character other than constitutional interpretation, then the power remains unchecked. These are theoretical concerns which show the inappropriateness of the $\mathrm{HoF}$ as constitutional adjudicator. There are also practical reasons, discussed below, which show gaps in HoF's operations as an impartial and strong constitutional adjudicator.

${ }^{171}$ In practice, the EPRDF and its affiliates control all the nine regional states, and state councils of each regional state sends representatives from state executive. This shows that the members of the HoF are in practice politicians from the state executive.

${ }^{172}$ The Case of Kontoma Community who lives in the Guraghe Zone of Southern Nations, Nationalities and People's regional state (SNNPRS) recently claimed that they have distinct identity that qualifies the requirements under the Constitution and they are suffering from discrimination from other ethnic groups. After undertaking a research on the issue, both the SNNPRS and the HoF decided that the group does not fulfil the requirements under the Constitution. The representatives of the Community brought a constitutional complaint to the Council of Constitutional Inquiry against the decision of the HoF alleging that their constitutional right has been violated. The Council, in its latest session, stated that it has no power to review the constitutionality of decisions of the HoF. 


\subsection{The role of the Council of Constitutional Inquiry}

The CCI is the advisory body for the $\mathrm{HoF}$ in its task of constitutional interpretation. As it has been mentioned above, it is chaired by the President and the Vice President of the Federal Supreme Court as President (Chairperson) and Vice President (Vice Chairperson), six legal experts to be appointed by the President of the country upon recommendation by the Parliament, and three representatives of the House of Federation. ${ }^{173}$ In general, out of its eleven members, at least eight are legal experts while there is no such requirement for members assigned by the HoF. The composition of the CCI makes it a technical body that assists the HoF.

In China and Ethiopia, the assemblies interpreting the constitutions are respectively assisted by the Standing Committee of NPC and the CCI of the HoF. However, the CCI is different in structure, composition and powers from the NPCSC of China. First, unlike the NPCSC, the CCI is not an organ that operates as permanent body of the HoF. It is rather an advisory body empowered 'to investigate constitutional disputes' and make recommendations to the $\mathrm{HoF}$ if it finds that interpretation of the Constitution is necessary. ${ }^{174}$ Hence, the CCI does not take part in other functions of the HoF than constitutional interpretation.

Secondly, its composition is different from the NPCSC. The latter is composed of the Chairman, the Vice-Chairmen, the Secretary-General and Members of the NPC, who may not be lawyers, whereas the CCI, as mentioned above, is mainly composed of lawyers. The composition of these organs indicates the purposes for which these entities are created: NPCSC is created as permanent body of the NPC whereas the CCI is created to technically support the $\mathrm{HoF}$ in constitutional interpretation.

With regard to the procedures of complaint, Proclamation No. 798/2013 clearly indicates who could bring cases to the HoF/CCI. ${ }^{175}$ According to Article 4 of this Proclamation, any interested party who claims constitutional violation by a legislation, regulation or administrative decision may apply to the HoF/CCI for review of constitutionality if it has exhausted local remedies. If the case is justiciable, courts should refer the constitutional issue to the CCI either upon request by the parties to the case or the court's own initiative. When compared

${ }^{173}$ Article 82 of the Constitution of FDRE. The earlier draft of this Article had suggested 6 members to be elected by the HoF whereas legal experts appointed by the President of the Republic were three. It was changed into the current composition with a view to strengthen the technical support that the CCI is expected to give to the HoF. See Minutes of the Constituent Assembly, Vol. 5, p. 1.

${ }^{174}$ Article 84 of the Constitution of the FDRE.

${ }^{175}$ When the HoF receives complaints, it refers it to the CCI for recommendation. 
with China, there are indeed clear provisions regarding who could bring cases to the $\mathrm{HoF} / \mathrm{CCI}$.

The CCI is a key institution in constitutional adjudication, and most recommendations of the CCI are accepted by the HoF even if there are some cases where the latter departed from the opinion of the CCI and passed its own decision. ${ }^{176}$ There are some constraints that hinder the $\mathrm{CCI}$ from playing its part towards the enhancement of constitutionalism in Ethiopia. First, the Constitution establishes the CCI under Article 82 (in the section that deals with the judiciary) which is silent about CCI's autonomy. Even if it is an advisory body, genuine autonomy would enable the CCI to proactively engage in constitutional adjudication and show to what extent the organs of the government are observing the Constitution. This active role would put pressure on the political bodies to observe the Constitution as recommendations of the CCI would make them vulnerable politically. Article 62(2) of the Constitution provides that the $\mathrm{HoF}$ has the power to organize the CCI. It is not clear how far this power to 'organize' could go, and hence leaves the door open for the HoF to control, and even give instruction to the CCI. Clear indication of the independence and autonomy of the CCI under the Constitution would have enabled it to play a much better role.

Secondly, the limited frequency of meetings of the CCI, i.e., at least once a month, ${ }^{177}$ adversely affects its performance. A separate secretariat has been established by Proclamation No. 798/2013 due to the growing volume of cases submitted to the HoF. Although Article 83 of the Constitution requires the $\mathrm{HoF}$ to decide a constitutional dispute within thirty (30) days, the steadily growing number of complaints takes more time to render decisions than the timeframe stated in the Constitution. Thirdly, there is no requirement, under the Constitution that demands the political neutrality of the legal experts appointed by the President of the Republic. This opens the door for stronger political influence on the CCI as the Parliament recommends politically affiliated legal experts.

\subsection{Practical implications}

It has been more than two decades since the 1995 Constitution of Ethiopia is enacted. This period is long enough to enable us examine whether the arrangement on constitutional adjudication is achieving its purposes. The

\footnotetext{
${ }^{176}$ The Benishangul Gumuz Case could be mentioned as an example where the HoF took its own position. See Benishangul Gumuz Case, Journal of Constitutional Decisions, The House of Federation of the Federal Democratic Republic of Ethiopia, July 2008, Vol. 1.

${ }^{177}$ Article 23 of Proclamation No. 798/2013.
} 
practices of the HoF/CCI should thus be examined in light of the aspirations and pledges of the framers. ${ }^{178}$

Since the enactment of the 1995 Constitution, more than 2,900 (two thousand nine hundred) cases were filed (until February 2018) in the CCI for review of constitutionality, and most of the cases were individual complaints brought against judicial decisions. ${ }^{179}$ This number looks larger when it is compared with the Chinese counterpart or with France's Sénat or Brazil's Assembly. Among these cases, it is only in 24 cases $^{180}$ that the CCI found legislation and acts of government organs unconstitutional. ${ }^{181}$ Most of the cases where the HOF/CCI decided unconstitutionality are individual complaints brought to them mostly against judicial decisions.

Among the cases adjudicated by the HoF/CCI, since their establishment under the Constitution, only few cases were related to rights of NNPs, and it was in one case that the $\mathrm{CCI} / \mathrm{HoF}$ found unconstitutionality in its review. ${ }^{182}$ Recently, the growing number of claims relating to the rights of NNPs indicates the growing ethnic consciousness among groups.

This practical evidence thus substantiates the flaws in the design on constitutional adjudication thereby disproving the framers' fear because issues relating to nationalities have (since 1995) come to the scene of constitutional interpretation very rarely. Surprisingly, the organ that passes decisions on issues relating to identity and exercise of rights of NNPs is the HoF. Ordinary courts cannot entertain such cases on the ground that they are not justiciable even in the absence of a restriction to interpret the Constitution. As it was mentioned in the dissenting opinion among the members of the Constituent Assembly, it

${ }^{178}$ The data is obtained from annual reports of the CCI as the decisions of both the HoF and the CCI are not available on their website or publication except the first four landmark cases which are published.

${ }^{179}$ This number was found from anonymous source working in the Secretariat of the CCI.

${ }^{180}$ Ibid. Most of these cases were decided after the CCI got its secretariat separate from the $\mathrm{HoF}$ in 2013.

181 Most legislation (the constitutionality of which was challenged like anti terrorism legislation, broadcast and media legislation, Regulation of emlpoyees of Revenue and customs authority) were found to be constitutional despite their clear contradiction with the Constitution.

${ }^{182}$ See the Silte Case, Journal of Constitutional Decisions, The House of Federation of the Federal Democratic Republic of Ethiopia, July 2008, Volume 1, pp. 40-100; The Case of Benishangul Gumuz could also be mentioned as an example. Recently, questions of the People of Qimant, Welkaite and Kontoma Community may be added to the list. See Ruling of House of Federation, on 4th Parliamentary Term, 5th Year, 2nd Regular Meeting, 24th June 2015, Unpublished; Decision of Council of Constitutional Inquiry, File No. 1459/2015, 22 June 2016, unpublished. 
would have been better if the HoF had been empowered to interpret the Constitution only in cases involving rights of NNPs. Such an arrangement would have been adequate to protect rights of NNPs, on the one hand, and meanwhile ensure stronger judicial review. The framers' fear of what they called 'constitutional crises' would not have been a threat to constitutionalism as much as designing such weak constitutional review mechanism.

In the Ethiopian context, issues of violations of fundamental rights -rather than rights of NNPs- are the most frequently lodged constitutional complaints. Strengthening schemes of check and balance through review of constitutionality is among the measures that restore peace and create a stable democracy. Given the fact that people in many parts of Ethiopia, particularly in Oromia and Amhara Regional States, protested ${ }^{183}$ in the quest for better protection of human rights, lack of good governance and equality verifies this point. Hence, the facts on the ground verify that the issue of stronger constitutional review in Ethiopia is expedient, and that the framers of the 1995 Constitution have unduly exaggerated the potential violation of rights of NNPs. Mere focus on collective rights such as rights of NNPs becomes futile unless individual rights are simultaneously ensured, and this requires a strong mechanism of constitutional review as one form of check and balance.

\subsection{Lessons for Ethiopia from the experiences across time and space}

The experiences of older constitutions around the world regarding constitutional adjudication by legislative bodies/assemblies should give lessons to similar contemporary designs. The current Ethiopian Constitution, as a late comer, should have learned from the past lessons of failures. When the Ethiopian experience is compared with that of France and Brazil, it may seem that it is relatively better because there are some cases decided by the HoF/CCI. However, unlike pre-1946 France and pre-1891 Brazil, we are living in the $21^{\text {st }}$ Century where constitutionalism has become more global and citizens everywhere are more conscious of their rights.

The demand for the protection of fundamental rights and constitutionalism through strong constitutional review has become an issue in Ethiopia. In light of the failure of similar arrangements in France and Brazil, and owing to failures of constitutional adjudication in China, the necessity of responding to the demands of better protection of rights of citizens and ensuring constitutionalism is necessary. There should thus be a constitutional reform regarding who should interpret the Constitution.

${ }^{183}$ For details of the situations of the protests, see, for instance Awol K. Allo, 'The Oromo protests have changed Ethiopia', available at:

<http://www.aljazeera.com/indepth/opinion/2016/11/oromo-protests-changed-ethiopia161119140733350.html>. 
Constitutional interpretation has important tasks of ensuring the supremacy of the constitution, protecting fundamental rights and keeping balance among government organs. Weak constitutional review mechanisms fail to achieve these purposes. The experiences clearly show that (non-)legislative parliaments are not appropriate organs to interpret constitutions. Therefore, Ethiopia should draw lessons from the historical and contemporary experiences of the jurisdictions under consideration.

Empowering (non-)legislative assembly to interpret a constitution is not an invention of the Constitutions of China or Ethiopia; nor is it something that has never been tried in the constitutional histories of nations around the globe. The experiences of France between 1789 and 1946 and that of Brazil between 1824 and 1891 should serve as a test whether parliaments can successfully exercise the power of constitutional adjudication. Both experiments failed thereby necessitating a different institution for constitutional interpretation. It could be discerned from the constitutional history of France and Brazil and that of the contemporary arrangement in China that the Ethiopian Constitution which authorizes constitutional adjudication by $\mathrm{HoF}$ needs to be amended. In addition to the theoretical criticisms forwarded against the $\mathrm{HoF}$ as constitutional interpreter, its practical problems and failures should indeed give a strong message that at this point in time, an independent body should be authorized to adjudicate constitutional disputes.

\section{Conclusion}

Constitutional adjudication is one of the aspects of modern constitutional law especially in countries where there is a written constitution. The reasons for constitutional interpretation include ensuring supremacy of the constitution, limiting powers of the government, and keeping the balance of powers in federations. There are variations in the institutions empowered to adjudicate constitutional issues. Two models of constitutional adjudication are widely accepted. In the diffused model of judicial review, ordinary courts at all levels can exercise constitutional review by reserving the power to render authoritative interpretation to the Supreme Courts; and the centralized model of judicial review entrusts a specialized court with the task of constitutional adjudication.

On the other hand, constitutional review by (non-)legislative assemblies has failed to be effective (as discussed in the preceding sections). In this regard, lessons can be drawn from the constitutional history of France and Brazil and from contemporary China. The failures in France, Brazil and China should give lessons to Ethiopia that constitutional adjudication by parliaments is ineffective. The Sénat of France failed because it was a political body and had no interest to exercise the power. A similar logic could apply to Brazil. Their experience shows that constitutional adjudication by parliaments could not work and 
achieve the desired purposes of interpreting constitutions. The institutional choice in Ethiopia in 1995 could have indeed been informed by the failed experience of France, Brazil and China.

The Constitutions of China and Ethiopia empower (non-)legislative assemblies -the NPC/NPCSC and the HoF/CCI- to interpret the constitution. Current trends of constitutional review in China and Ethiopia indicate that the NPC and the HoF are not properly exercising their power of constitutional adjudication. Their political affiliation resulting in the absence of the requisite impartiality, lack of interest to exercise the powers and rare meetings per year, are among the factors that render these institutions ineffective in exercising their powers. These lessons show that the need for reforming the institutional choices of Ethiopia in constitutional adjudication is long overdue. 